\title{
'n Reformatoriese perspektief op sin en identiteit
}

\author{
Magda van Niekerk \\ Departement Afrikaans \& Nederlands (Kunsgeskiedenis) \\ Potchefstroomse Universiteit vir $\mathrm{CHO}$ \\ POTCHEFSTROOM
}

\begin{abstract}
This anicle addresses the ullimate question regarding meaning and the closely related problem of identity from a reformational vantage point. Although the human being's central or religious identity can be distinguished from his various functional identities, the importance of personality integration (consonance between these two dimensions of identity) is stressed. The central identity of the Christian is rooted in Christ, a point of departure which means reconciliation with God and provides the basis for reconciliation with himself, with his neighbour and with creation as a whole, thus eliminating in principle the alienation that has characterised cach of these relations since the fall. A person's religious orientation towards the true Origin functions as a necessary condition for his awareness of creation as meaningful, i.e. its dependence on its Creator. In identity development the historical principles of continuity, differentiation and integration are impontant. Reference is made to various aspects of identity, like self-image, -knowledgc and-trust, as well as to the imporance of Scriptural revelation of creation, fall and redemption for a true view on the human self and on a person's functional identities. It is pointed out that differing answers to the question of meaning are implicitly present in scientific theories. A person's utimate commitment mav thus not be isolated from his scientific endearours.
\end{abstract}

\section{INLEIDING}

Vir mense van allerlei oortuigings is dit van belang om 'n antwoord te kry op die vraag na sin. Vir die meeste mense is dit alles behalwe 'n retoriese vraag en is die antwoord hierop glad nie vanselfsprekend nie. Rossouw (1981:11) het geen twyfel daaraan nie dat "... die grootste bedreiging van die mens nie ongemak of onkunde is nie, maar onsin". Wanneer onsekerheid hom van die mens meester maak, omdat sy tydelike sekuriteite, dinge soos finansiële voorspoed, gesondheid, politieke mag, beroepsukses ensovoorts - wat soms tot finale sekerhede verabsoluteer is - onder hom uitgeruk word, kom hierdie vraag dikwels akuut na vore. Ook die Christen mag egter nie die vraag na sin verdring nie, maar moet ' $n$ antwoord daarop daagliks met sy hele menswees uitleef. En dit is iets anders as om te leef vanuit 'n burgerlike moraal, vanuit die lewensinstelling van die gearriveerde mens wat homself so geborge voel in tydelike sekuriteite dat hy geen las meer het van grensvrae soos: 'Wie is ek werklik?' en: 'Wat is die sin van alles?' nie.

Koers 58(1) 1993:53-70 
Een van die wetenskappe wat eksplisiet aan die sinvraag aandag gee, is die Psigologie. Laasgenoemde wetenskap konfronteer egter die soeker na 'n antwoord op hierdie vraag met 'n groot verskeidenheid moontlikhede (vergelyk Maddi, 1976:649-672): Is die sin van menslike bestaan geleë in die vermeerdering van instinktiewe bevrediging en vermindering van straf en skuld soos by Freud, of is dit geleë in die suksesvolle krisisoplossing in elke lewensfase soos by Erikson? Bestaan die sin van die lewe in die bereiking van 'n gebalanseerde selfheid tussen die opponerende kragte van die persoonlikheid soos by Jung, of miskien in die aktualisering van die mens se eie potensialiteite soos by Rogers en Maslow? Of moet dit dalk eerder gesoek word in die strewe na 'n volmaakte sosiale samehorigheidsgevoel waarin die individu optimaal tot sy reg sal kom soos by Adler? Is sin miskien eerder daarin geleë om self-ekspressief volgens propriale strewes te funksioneer, soos by Allport, of om as mens werklik menslik en nie op animale wyse te funksioneer nie, soos by Fromm, of om 'n ware outentieke mensebestaan te bereik deur die menslike keuse-vryheid uit te oefen soos by Frankl? Moet 'n antwoord op die sinvraag gesoek word in rasionele pogings om ervarings en gebeurtenisse te voorspel en te beheer, soos by Kelly? Of moet die sinproblematiek ontken of onderbeklemtoon word omdat die mens slegs of hoofsaaklik 'n geaktiveerde wese is volgens die spanningsverminderings- en stimulus-respons-model van die behavioriste?

Die antwoorde op die sinvraag blyk dus baie uiteenlopend te wees - meer nog, dit skyn asof ' $n$ mens nie deur middel van sy rede by 'n bevredigende antwoord op hierdie vraag kan uitkom nie. In hierdie artikel, wat die derde een in 'n reeks van drie is, word gepoog om 'n uiteensetting te gee van 'n reformatoriese visie op die sinvraag en op die menslike identiteitsproblematiek. In die vorige twee artikels (Van Niekerk, 1991a; 1992) is in gesprek getree met 'n verskeidenheid nie-reformatoriese benaderings tot sin en identiteit. Hierdie benaderings val breedweg uiteen in of deterministiese en getemperde deterministiese bydraes enersyds, of personalistiese bydraes andersyds.

Binne eersgenoemde kategorie is sowel dieptepsigologiese as behavioristiese standpunte geïdentifiseer as benaderings wat gebaseer is op 'n deterministiese mensbeeld. 'n Deterministiese mensbeeld blokkeer by Freud, sowel as by Watson en Skinner, by voorbaat 'n besef van die belang van die sinvraag, hoewel ' $n$ implisiete beantwoording van hierdie vraag in hul teorieë meespeel. Die implisiete beantwoording van die sinvraag geskied naamlik deur benede-normatiewe fasette soos die biotiese en die psigiese te verhef tot oorsprongsidee van waaruit menslike funksionering ontspruit. Hierdeur word tegelykertyd die verskeidenheid in menslike motiverings op monistiese wyse gereduseer tot 'n enkelvoudige funksioneringswyse van of drange of aangeleerde gewoontes - 'n benaderingswyse wat op geen wyse die religieuse gerigtheid van die mens verreken nie. In ooreenstemming hiermee word identiteit vereenselwig met die benede-normatiewe neerslag van natuurnoodwendighede of van 
eksterne kulturele noodwendighede (in die vorm van leerprosesse waaroor die mens weinig of geen beheer het nie) op die mens se persoonlikheid.

Die tempering van klassieke Freudiaanse en behavioristiese opvattings wat deurgaans in die nuwere verwerkings van hierdie rigtings sigbaar word, ${ }^{1}$ is positief gewaardeer, omdat die reduksionisme van die aanvanklike uitbouers daarvan in ' $n$ belangrike mate aan bande gelê is. Hierdeur het 'n vollediger visie op die mens na vore gekom en word sy gedetermineerdheid grootliks in ewewig gehou deur ' $\mathrm{n}$ klem op die vryheid van tipies menslike beslissingsmoontlikhede (Van Niekerk, 1991a:136).

In personalistiese psigologiese bydraes, soos dié van Rogers, Allport, Maslow en Frankl, kom die menslikheid van die mens in 'n groter mate tot sy reg as by die deterministiese benaderings, maar die oorbeklemtoning van vryheid in personalistiese teorieë roep om 'n geïntegreerde mensbeeld, waarin die mens se natuurlike strukture ${ }^{2}$ wat onder normatiewe leiding staan, verreken word. Hierdie mensbeeld moet veranker word in 'n religieuse perspektief, met ander woorde in die besef dat die mens se hartsgerigtheid 'n deurslaggewende rol speel in sy belewing van sin en in sy identiteitsbesef en -vorming. Sonder ' $n$ visie op die mens se religieuse verankering is daar immers geen prinsipiële basis vir 'n visie op die mens as eenheid nie, en sou ook persoonlikheidsintegrasie en 'n geïntegreerde funksionering hoogstens op pragmatiese en empiriese gronde verdedig kon word.

Ten spyte van die erns waarmee kwessies rondom sin en identiteit in sommige van die psigologiese rigtings aangepak is, ervaar die reformatoriese wetenskaplike steeds probleme met die gangbare standpunte. Dit is trouens as 'n ernstige leemte gevoel dat sin nie gedefinieer word as 'n gegewe wat die skepping as totaliteit omvat nie en dat meestal slegs gepoog word om rekenskap te gee van die individuele ervaring van sin. Dit strook egter nie met 'n Bybelse visie op die totale werklikheid as God se kosmos nie. Bowendien word met die oorbeklemtoning van menslike vryheid die konsekwensies getrek van die menslike outonomiestrewe wat geboorte gegee het aan die moderne subjektiwisme. Voorts dui 'n onderbeklemtoning van die mens-in-gemeenskap op 'n individualistiese uitgangspunt. Wie egter God as die enigste Absolute erken, moet alle verabsoluterings of -ismes vermy, ook subjektiwisme en individualisme. Dit blyk noodsaaklik te wees om 'n eie beskouing waarin die samehang tussen sin en identiteit

1 Voorbcelde is dic bydracs van Jung, Adler, Horney, Fromm cn Erikson in dic Freudiaanse tradisie, en Kelly en Ellis, wat as kogniticwe psigoloë breedweg tot dic neo-behavioristiese rigtings behoort.

2 Hicr word verwys na die mens se fisiese, biotiese en psigiese strukture, sowel as die necrslag van allerlei oorerflike en omgewingsfaktore op hierdie strukture. 
in die verskillende dimensies daarvan duideliker na vore kom, uiteen te sit. Dit sal geskied onderhewig aan Skrifperspektiewe en in aansluiting by denkers binne die reformatoriese tradisie.

\section{BEGRONDING}

\subsection{Skriftuurlike uitgangspunte}

Dit is in die eerste plek nodig om te beklemtoon dat dit nóg die taak van enige vakwetenskap soos die Psigologie, nóg die taak van die Filosofie as totaliteitswetenskap is om die vraag na die sin van die werklikheid vir die mens te beantwoord. Immers, slegs die Skrifgeworde en die vleesgeworde Woord openbaar aan die mens die sin van die skepping, die geskiedenis, die voleinding en die sin van sy eie individuele bestaan. Alleen deur die gawe van geloof verkry die mens ware kennis aangaande die sin van sy bestaan. En geloof is nie 'n resultaat van wysgerige of vakwetenskaplike besinning nie, maar gaan daaraan vooraf. Kalsbeek (1970:76-77) stel die basis van'n voorwetenskaplike Bybelse hesef van sin, soos aanvaar in die reformatoriese tradisie, soos volg:

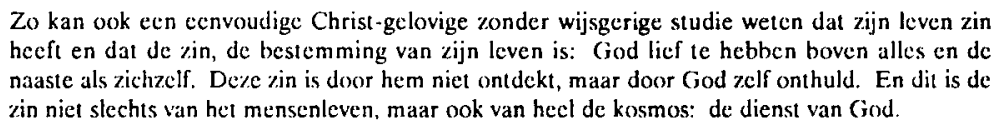

zin niet slechts van het mensenleven, maar ook van heel de kosmos: de dienst van God.

Die mens se voorteoretiese en selfs bo-rasionele insig in sin dien dus vir die filosofiese en vakwetenskaplike besinning as grondslag en nie andersom nie. Anders gestel, die Skrif verskaf geen teoretiese antropologie nie, maar gee aan ons 'n visie op die mens, naamlik dat hy nooit onathanklik en outonoom is nie, maar as totale mens voortdurend in 'n verhouding tot God staan (Olthuis, 1985:1). Vanuit hierdie Skrifgeloof kan die wetenskaplike dit erns maak met die geloofswaarheid dat die mens 'n hart, siel of gees het wat in eksistensiële sin op Gods Woord moet antwoord en die sin van sy bestaan vind in die lewensomvattende diens aan God met sy hele hart.

\subsection{Basiese antropologiese beskouings}

Op grond van hierdie voor-wetenskaplike geloofswaarhede moet daar by die uitbouing van 'n reformatoriese antropologie gewaak word teen 'n dualistiese mensopvatting 
waar 'n deel van die mens as laer en tweederangs geklassifiseer word. Daarby moet ook die slaggate van 'n funksionalistiese mensbeeld vermy word, waardeur die gesentreerdheid van die mens in sy funksionering verlore raak. Ook individualistiese en kollektiwistiese visies op die mens, waar of die individu, ó die gemeenskap oorbeklemtoon word, is onaanvaarbaar (vergelyk Olthuis, 1985:3).

Tekenend van antropologiese bydraes binne die reformatoriese tradisie (Dooyeweerd, Troost, Strauss, Olthuis, Ouweneel, Smit en ander) is ook dat die mens nie reduksionisties tot een van sy aspekte of strukture herlei word nie, maar dat daar'n verskeidenheid strukture van die mens onderskei word, te wete die fisies-chemiese, biotiese, psigiese en aktstruktuur. Smit (1988:7) is van mening dat daar eerder van die normatiewe struktuur as van die aktstruktuur gepraat moet word. en Ouweneel (1984b:165-184) bring ' $n$ verdere differensiasie in die psigiese struktuur aan in sy onderskeiding tussen 'n perseptiewe en 'n sensitiewe struktuur, wat egter deur Smit (1988:7-8) nie as deurslaggewend vir 'n Christelik-antropologiese model beskou word nie en ewe-eens deur Cronjé (1990:36-37) gekritiseer word. Sowel Ouweneel as Smit sluit aan by Troost (1958:375-384) se beskouing van die etos as die eerste uitdrukking van die religieuse hart in die mens se lewe. Alle menslike intensies en handelinge vanuit die hart word via die etos religieus bepaal. Ouweneel (1984a:93) verduidelik dat hy onder die etos die tipies menslike waardes verstaan. Ten spyte van kleiner verskille stem die genoemde outeurs egter ooreen in die erns waarmee hulle poog om 'n antropologie te ontwerp waarin Skriftuurlike perspektiewe 'n duidelike rol speel. ${ }^{3}$

Die menslike strukture is interafhanklik en vervleg met mekaar, sodat geen dualisme (byvoorbeeld tussen siel en liggaam) danvaar word nie, maar die mens sy eenheid vind in die hart as konsentrasiepunt van sy persoonlikheid en bestaan, 'n persoonlikheidskern wat egter altyd op God of op 'n afgod gerig is. Dit is belangrik om daarop te let dat die aktstruktuur tot die volle liggaamlikheid van die mens behoort en dat die siel nie vereenselwig mag word met verselfstandigde funksies van die aktstruktuur of van die menslike sensitief-psigiese struktuur nie (Strauss, 1979:12). Die hart van die mens vind juis in die liggalam, wat die aktstruktuur insluit, 'n veelsydige uitdrukkingsveld.

Dit is voorts belangrik om daarop te let dat die Christen se hartsverbintenis met sy Oorsprong nie slegs gaan om sy verhouding as individuele gelowige met Christus nie. Die Nuwe Testament lê immers met verwysing na die liggaam van Christus groot klem

3 Dit is nie moomlik om hier uitvoerig stit te stan by relevante diskussies in die reformatoriese tradisic sell nic - vir 'n kort samevatting hiervan, kyk Botha (1990:184-185). Op Wolterstorlf (1981:84-88) se probleme met de reformatoriese idec van religic is reeds relatief uilvoerig kommentatar gelewer (Van Nickerk, 1991b:22-26). 
op die gemeenskaplike verbondenheid van die herborenes in Christus. Hierdie verbondenheid is radikaal, sentraal en totaal, en word deur Strauss (1989:15) aangedui met die afkorting, "RST-verbintenis". Met laasgenoemde gee hy rekenskap van dit wat in hierdie artikel as die sentraal-religieuse identiteit getipeer word. Alle ander verbintenisse waaraan die mens mag deelhê, sy veelheid van funksies, is gedifferensieerd (omdat hulle uit die wortel vertak), periferaal (omdat hulle nie in die sentrum van die lewe staan nie) en gedeeltelik (omdat hulle nie die totaliteit van die menslike lewe omvat nie). Na aanleiding hiervan gebruik Strauss (1989:15) die afkorting, "GPG-verbintenis", waarmee hy rekenskap gee van die mens se verskeidenheid funksionele identiteite. Tussen hierdie twee dimensies van identiteit is daar normaalweg 'n intieme samehang en ontvang die funksionele identiteite profiel vanuit die dieper sentraal-religieuse identiteit. Dit beteken dat Christenskap nie iets aparts van die daaglikse lewe is of dat dit 'slegs gaan om die redding van die siel' nie, maar dat dit op die mens ' $n$ appèl uitoefen om in elke gedifferensieerde hoedanigheid ${ }^{4}$ te leef vanuit hierdie RST-verbintenis. Juis hierin is die mens uniek tussen alle skepsels.

Dit wat volgens Bybelse standpunt die mens uniek maak, is ook die sin van mens-wees, naamlik die mens se roeping van Godsweë "... om met verantwoordelike vryheid sy kultuuropdrag in 'n egte, lewensomvattende Koninkryksgehoorsaamheid ten uitvoer te bring" (Strauss, 1979:13). Hierdie lewenswydheid van die menslike sinbelewing word ook deur Botha (1978) beklemtoon, aangesien die vraag na die sin van mens-wees saamhang met die vraag na die sin van menslike kultuurbeoefening, sodat die sinvraag en sinkrisis van ons tyd die hele spektrum van menslike kultuurbeoefening raak. Immers, waarom sal die mens die moeite doen om kultureel-vormend besig te wees as hy geen sin daarin sou sien nie?

\subsection{Die sin-karakter van die werklikheid}

Binne die kring van die reformatoriese filosofie was dit veral Dooyeweerd as grondlegger van die 'Wysbegeerte van die Wetsidee' wat uitvoerig aandag aan die sinkarakter van die werklikheid bestee het. ${ }^{5}$ Volgens hom (Dooyeweerd, 1953:4) moet erken word dat alles wat geskape is, sin is, en daarmee bedoel hy die onselfgenoeg-

4 Voorbeelde van gedifferensicerde funksies is die mens as kerklidmaat, as cggenoot cn oucr, staatsburger, kunswaardeerder, koper/verkoper, vriend/buurman, taalgebruiker, lid van 'n volk, wetenskaplike, ensovoorts.

5 Kyk Dooycweerd (1955:25-30) in verband met die onderskeid tussen sy eie sin-opvatting en dié van die immancnsicfilosofic, asook vir sy kritick op laasgenoemde. 
saamheid van die skepping, dit wil sê die feit dat niks uit sigself, op sigself of ter wille van sigself bestaan nie, sodat die totale skepping heenwys na die Skepper (Dooyeweerd, 1953:10). In ooreenstemming met die Bybelse openbaring aangaande hierdie afhanklike betrokkenheid van die ganse skepping op God, mag die skepping dus nooit los van die Skepper gesien word nie. Die geskapene (lewelose en lewende dinge, die mens en die totaliteit van sy kultuur) bestaan slegs in verhouding tot God, in onderworpenheid aan sy wet, skeppingsraamwerke of verordeninge wat deur Christus in stand gehou word (Dooyeweerd, 1953:97). Hierdie verhouding bly gehandhaaf ten opsigte van die ontstaan, voortgang en voleinding van die totale werklikheid. Die afhanklike bestaan van die skepping is nie star of staties nie, want die Bybelse sin-idee sluit die idee van die sin-dinamiek in, aangesien God self die moontlikhede en die roeping gegee het tot verdere ontdekking en ontplooiing, ontsluiting of aktualisering, ook deur menslike kultuurarbeid. Hierdie moontlikhede en roeping bly voortbestaan, selfs al kan die mens as gevolg van die sonde nie meer die skepping tot volle ontplooiing bring nie (Kalsbeek, 1970:79).

Alleenlik God is selfgenoegsaam, terwyl die sin-karakter van die geskapene juis dui op laasgenoemde se betreklikheid, op die relatiwiteit daarvan, op die feit dat dit steeds in verhouding tot God as die sin-gewer staan. Sin word dus deur Dooyeweerd (1955:32) gedefinieer as die bestaanswyse van die ganse geskape werklikheid in afhanklikheid van die Skepper. Die radikale humanisme as teendeel hiervan dui op die lewensinstelling van die soewerein-gewaande mens wat soos God wil wees, oor homself wil beskik en sowel die oorsprong, asook sy eie wêreld na sy eie beeld wil herskep (vergelyk Dooyeweerd, 1972:48). Sodanige lewensinstelling beteken 'n ontkenning van die mens se afhanklikheidsverhouding tot God en daarom ook 'n ontkenning van sin soos in Bybelse terme verstaan.

Dooyeweerd (1955:33-34) wys egter tereg daarop dat die mens se pogings tot selfgenoegsaamheid nie die sin-karakter van die werklikheid kanselleer nie - niks kan die skepping aan hierdie sinvolheid, hierdie afhanklikheidsverhouding onttrek nie - dit is Gods instandhoudende genade. Daarom het die lewe nie net sin in soverre die mens self daarin sin sien nie (Valenkamp, 1989:12). Wat dergelike pogings tot selfgenoegsaamheid wel veroorsaak, is 'n verlies aan ervaring van ware sin by die mens self, sodat hy en sy wêreld hoogstens 'n gewaande outonomie verkry. Die synswyse van die mens as religieuse skepsel van wie die hart steeds onrustig soek na 'n vaste punt vir sy bestaan, ${ }^{6}$ en wat hierdie vaste punt nêrens in die ewe onselfgenoegsame skepping

6 Kyk Frankl (1970:165-181) vir 'n beskrywing van 'n gevallestudie van 'n vrou wat vanweë 'n religieuse krisis onrustig-soekend gebly het - tot haar hart in God rus gevind het. 
kan vind nie, impliseer egter dat hierdie 'outonomie' 'n kaartehuis is wat nie kan standhou nie. Die sin-volheid van die ganse skepping is immers geleë in Christus Jesus op wie alle dinge betrokke is en wat steeds die sin-versteurende werking van die sonde teenwerk (Dooyeweerd, 1955:25). Anders gestel, die mens kan slegs die ware sin van sy bestaan in en deur Christus ontdek, en dan eers die juiste antwoord op die vraag na die oorsprong en die bestemming of sin-vervulling van alle dinge verkry (vergelyk Van Niekerk, 1986:188).

\section{IMPLJKASIES EN UITWERKING}

\subsection{Vervreemding teenoor versoening}

Sonder bogenoemde vaste punt vir sy bestaan kies die mens om sy lewe in te rig volgens sy vermeende onafhanklike outonome keuse (soos by die sondeval gebeur het) en nie in gehoorsaamheid aan Gods Woord nie. Die gevolg hiervan is vervreemding van die mens van God, soos na vore kom in 'n knieval voor ideologieë. ${ }^{7}$ Die mens word egter hierdeur ook ontmenslik, met ander woorde hy word van homself en van die sin van sy bestaan vervreem as hy God se bedoeling mis (naamlik om Hom alleen te verheerlik).

Terwyl vervreemding in verskillende tye en omstandighede verskillende gedaantes kan aanneem, kom dit in moderne Westerse samelewings by uitstek na vore in 'n konstante spanning tussen die rasioneel-wetenskaplike kultuur enersyds, en die irrasionele, 'menslike' verset daarteen andersyds, wat daarop aanspraak maak dat dit die vervreemding wat wetenskap en tegniek meebring, teenwerk. ${ }^{8}$ Botha (1987:11) wys daarop dat hedendaagse kultuurprodukte in 'n groot mate die vrugte van die sekularisasieproses is, dit wil sê dit is "... simptomaties van 'n kultuur wat die produk skyn te wees van 'n geslote wêreld waarin die uitsig op God en sy bemoeienis met die wêreld verdwyn het en die menslike lewe aan alle kante ingesluit is deur die oormag van die mens se kultuurwerke". Hierteenoor omskryf sy 'n verantwoorde instelling teenoor die kultuur nie as een van negatiwisme of pessimisme nie, maar ewe min as een waarin alles verwag sal word van die handewerk van die mens, aangesien wetenskap en

7 Vergelyk die ideologieë van die sciëntisme en Marxisme, soos onderskeidelik behandel en in perspektief geplaas deur Ouwenecl (1987) en Fowler (1983).

8 Vergelyk ook Rookmaaker (1978a:29-49) waar hy aandag skenk aan die tendens onder vele moderne kunstenaars om doelbewus irrasionalisties te wees, uit reaksic teen dic lang tradisic van rasionalisme en teen die tegnokratisme van ons eeu. 
tegniek immers nie bedoel is om te ontaard in 'n beheersing van die aarde deur die outonome mens nie, maar om deur diensbaarmaking daarvan aan God, die naaste en die hele skepping, mee te help om die voorwardes te skep tot optimale lewensontplooiing met die oog op roepingsvervulling (Botha, 1987:15).

In teenstelling met die oorspronklike sin van die menslike bestaan en van sy kultuur maak vervreemding hom van die menslike situasie meester in die bedeling na die sondeval. Vervreemding in intermenslike verhoudings kom na vore in die stryd tussen mense in 'n bykans oneindige aantal gedaantes. Daar vind egter ook 'n vervreemding van die lewe plaas, waardeur die realiteit van die dood oppermagtig word. Ten slotte word die mens ook vervreem van die aardse skepping, aangesien dit wat hy moet bewerk en ontsluit, nou voortdurend weerstand bied teen sy kultivering en slegs met groot moeite ontsluit kan word (vergelyk Fowler, 1985:13-14).

Die mens wat outonoom wil wees, trek dus in werklikheid 'n streep deur sy ware menslikheid wat daarin bestaan om in 'n erkenning van sy sin-syn in afhanklikheid van sy Skepper te leef. Die mens wat meer as waarlik mens wil wees, wat vir homself goddelike outonomie toeëien en daardeur na selfverwesenliking strewe, word uiteindelik minder as 'n volwaardige mens: hy word ' $n$ wese wat ly onder die radikale en totale vervreemding van sy menslike selfheid en sy ganse lewe - van gewaande outonomie tot ontmensliking!9 Hierdie vervreemding is die finale oorsaak van enige diepgaande sin- en identiteitskrisis wat die mens mag ervaar.

Die teendeel hiervan is versoening, wat soos vervreemding radikaal en totaal is. Versoening met God kom na vore in sy weerstand teen ideologiese vergoddeliking van die geskapene; versoening met homself in 'n gebalanseerde (nóg meerderwaardige, nóg minderwaardige) belewing van sy eie-waarde in 'n verskeidenheid funksies, sowel as 'n belewing van sy sentrale identiteit as mens wat deel uitmaak van die nuwe mensheid in Christus; versoening met sy medemens in alle verhoudings waarin hy staan deur konkrete naasteliefde; versoening met die lewe, aangesien die angel uit die dood geneem is deur die ervaring van en uitsig op die ewige lewe wat reeds hier en nou begin, en versoening met die ru-stof (wat nie chaos beteken nie) van sy kultuuraktiwiteit deur die sin-syn van die geskape werklikheid met arbeidsvreugde na vore te bring.

9 Ter illustrasic hicrvan kan verwys word na die verskynscl van sogenaamde vrye liefde, waar die mens nic sy natuurlike drifte op 'n tipies menslike, verantwoordelike wyse onder normaticwc leiding wil plaas nie, en daarmee in werklikheid op 'n dierlik-instinktiewe vlak begin funksionecr. Omdat hy homself verhewe ag bo God se skeppingstrukture vir die mens, raak hy sy ware menslikhcid kwyt. 
'n Ware ervaring van sin is met ander woorde in die eerste plek afhanklik van die erkenning van God as die Oorsprong en Skepper van die totale kosmos en dus 'n erkenning van die sin-karakter van die geskape werklikheid, insluitende die mens. Sin is die onselfgenoegsame en heenwysende aard van die ganse kosmos. Daarby is 'n ware sin-ervaring ook afhanklik van 'n juiste insig in Christus se instandhouding van die werklikheid en die skeppingsverskeidenheid na die sondeval. Voorts is 'n ware en persoonlike ervaring van sin ook athanklik van 'n diepe besef van die eie identiteit se wortels, die besef dat die mens loot van die ware wynstok is, deel is van die nuwe mensheid in Christus. 10 Ten slotte word 'n ware sin-ervaring ook gedra deur'n eskatologiese visie op die voleinding en die herstel van die ganse skepping in en deur Christus. ${ }^{11}$ In teenstelling tot al hierdie fasette van versoening lei religieuse vervreemding tot 'n verlies aan ' $n$ ryk en lewensomvattende ervaring van sin.

Uit bogenoemde behoort dit duidelik te wees dat by 'n besinning oor die vraag na sin onvermydelik aandag gegee moet word aan die religieuse diepte-dimensie daarvan. Die mens se belewing van sin al dan nie is afhanklik van die gesteldheid en ingesteldheid van sy hart, soos gerig deur die grondmotief wat daarop heslag lê. Om hierdie rede reik ' $n$ sinbelewing veel dieper as wat na vore kom wanneer die mens vir homself bepaalde doeleindes stel of wanneer hy 'n sekere funksionaliteit of nuttigheidswaarde aan 'n spesifieke onderneming heg. Dergelike doeleindes kan trouens op die duur slegs as sinvol ervaar word as dit gedra word deur 'n geïnternaliseerde Bybelse werklikheidsbeskouing waarin skepping, sondeval, verlossing en voleinding as grondwaarhede in die geloof aanvaar en as persoonlike werklikhede beleef word.

\subsection{Die samehang tussen sin en identiteit}

Dooyeweerd (1955:500) definieer dit wat in hierdie artikel 'n 'sentrale identiteit' genoem word, soos voly:

10 Dooyeweerd (1953:(6) vestig die aandag daarop dat nic net die Christelike grondmotief nie maar ook alle ander grondmoticuc gemeenskapsmoticwe is, wat die menslike ekheid of ego saam mel ander ego's bind en groeper tor 'n geestelike gemecnskap, gerig op die Oorsprong of op 'n valse oorsprong, sodat by hom nie sprake is van 'n oorbeklemtoning van die individu, soos log by Frankl aanwesig is nie (vergelyk Frankl, 1985:60, 85).

11 Vergelyk hicrmec Frankl (1963:117) se observasies in die konsentrasickamp dat juis daardie konsentrasickampgevangenes wal geloof in hul tockoms verloor het, des te mecr aan psigiese en fisiesc verval bloolgestel was. Hicr moct egter beklemloon word dat 'n eskatologiese visie in Bybelse sin mecr en ook kwalitaticf anders is as die subjektiewe en individucle geloof van 'n mens in sy cic tockoms. 
The deeper identity experienced in our self-consciousness is of a transfunctional and supertemporal character. It is knowing onesclf to be one and the same in and beyond all cosmic temporal functions and knowing one's functions as one's own.

Hierdie identiteit gaan dus al die tydelike funksies (funksionele identiteite) van die mens te bowe, vervul 'n samebindende rol ten opsigte van sy veelheid aktiwiteite en akte, terwyl elk hiervan juis ervaar word as 'n geïntegreerde deel van sy eie menslike funksionering. Die religieuse gerigtheid van die sentrale identiteit is die primêre dryfkrag in die mens se lewe, terwyl die funksionele identiteit by die geïntegreerde mens hiervan 'n uitvloeisel is. Omdat nie alle mense egter oor 'n hoë vlak van persoonlikheidsintegrasie beskik nie en omdat die sentrale identiteit 'n saak van die hart is, staan die mens in sy beoordeling van ander mense hier voor 'n grens. Enige uitspraak oor die rigting waarin 'n mens se funksionele identiteit en sy gepaardgaande normbesef (of sy wetsidee in wetenskaplike sin) dui, kan dus slegs van 'n tentatiewe aard wees, sodat alle pretensies van absoluutheid by menslike oordele oor medemense vermy moet word. Die werklikheid van die sondeval moet steeds voor oë gehou word, asook die genade van Christus se verlossing. So 'n lewensingesteldheid skep 'n besef van eie feilbaarheid, sowel as van die feit dat ook die Christen lank nie altyd in ooreenstemming met sy status as nuwe mens in Christus handel nie.

Die sentrale identiteit is vanweë die religieuse aard van die mens se hart sodanig intiem verbonde met die sinvraag, dat laasgenoemde noodwendigerwyse die identiteitsvraag oproep en omgekeerd. Die sentrale dimensie van die mens se identiteitsbesef kom trouens juis na vore in sy implisiete en/of eksplisiete beantwoording van die sinvraag. In gevalle waar die Christelike opvoeding, die kerk en die Christendom 'n ekstrinsieke godsdienstigheid verteenwoordig en nie werklike intrinsieke waarde het nie (vergelyk Allport, 1961:302), word die opvoedeling en die kerklidmaat nie gelei tot 'n Skriftuturlik gefundeerde beantwoording van die sinvraag nie. Dit is tipies menslik dat daar vervolgens 'n soeke na 'n alternatiewe basis vir sinbelewing ontstaan, en die mens soek dan daarna in 'n verabsolutering van een of meer van sy funksionele identiteite. So ontstaan moderne idole soos rasionalisme, materialisme, estetisisme en dergelike meer. Indien die relatiwiteit daarvan tot die mens deurdring, byvoorbeeld indien die rasionalis tot die besef kom dat sy rede ook maar beperk is, kan dit tot ernstige eksistensiële probleme, insluitende sin- en identiteitskrisisse lei.

\subsection{Enkele historicse beginsels by identiteitsvorming}

'n Reformatoriese filosofie wat onder meer ' $n$ antropologie en 'n geskiedenisbeskouing insluit, bevat ook belangrike beginpunte vir'n besinning oor die vraag na die 
voorwaardes vir 'n harmoniese identiteitsvorming as ontplooiing en individualisering van die sentrale religieuse identiteit wat die mens volgens sy hartsgesteldheid besit. In 'n dinamiese ontwikkelingsproses vind die individualiserende vorming van die identiteit steeds plaas in onderworpenheid aan historiese beginsels.

Een van die belangrikste historiese beginsels is integrasie. ${ }^{12}$ Wie en wat die mens is, bly immers nie slegs 'in beginsel' nie, maar word in sy alledaagse handel en wandel in 'n verskeidenheid funksionele identiteite gekonkretiseer. Hierdie identiteite behoort religieus geïntegreer te word (met ander woorde, daar behoort ooreenstemming tussen die sentrale identiteit en die funksionele identiteite te wees) anders val die mens se lewe uiteen in kompartemente wat weinig met mekaar verband hou en raak hy sy identiteitsbesef kwyt. So kan die mens byvoorbeeld wat sy sentrale identiteit betref, 'n Christen wees, of 'n humanis, of 'n materialis, wat in geval van 'n geïntegreerde persoonlikheid 'n bepaalde rigting en stempel sal gee aan al sy lewensuitinge, vanaf sy logiese denke, sy historiese vorming, sy taalgebruik, sy sosiale lewe, sy ekonomiese, estetiese, juridiese, etiese en geloofsaktiwiteite. Al hierdie aktiwiteite sal dus by die mens met 'n geïntegreerde persoonlikheid in verband staan met sy sentrale identiteit, terwyl laasgenoemde 'n samebindende uitwerking op sy hele lewe sal hê.

By die vorming van ' $n$ mens se funksionele identiteit is daar naas die integrering van sy verskeidenheid rolle en funksies deur sy sentrale identiteit in 'n gedifferensieerde samelewing ook nog sprake van die historiese beginsel van differensiasie. Differensiasie impliseer dat die identiteit van 'n mens wat deel het aan 'n ontplooide kultuur, nie kan opgaan in of oorheers word deur een enkele rol nie, maar dat hy aan 'n verskeidenheid selfstandige lewensvorme deel het. So is die kunstenaar van ons eeu byvoorbeeld nie meer noodwendig gebonde aan 'n kultiese konteks vir sy kunsskepping, soos dit in ongedifferensieerde samelewings en selfs nog by die antieke Egiptiese en Griekse kuns die geval was nie, maar het hy nou selfstandig geword en kan hy op 'n vrye en verantwoordelike wyse 'n keuse maak ten opsigte van die lewensbeskoulike en funksionele konteks vir sy kuns. Die genoemde selfstandigheid dui egter nie op selfgenoegsaamheid nie, maar wel op die gedifferensieerdheid van die artistieke gemeenskap, wat naas ander lewensvorme in 'n gedifferensieerde samelewing bestaan en waaraan ook die kunstenaar deel het.

'n Voorwaarde vir 'n sinvolle, eietydse identiteitsvorming deur die hedendaagse mens is die positiewe aanvaarding van die differensiasieproses in die geskiedenis, waardeur

12 Kyk Dooycweerd (1955:260-261) in verband met differensiasic en integrasic as beginscls van die historiese proses. 
hy ' $n$ besef ontwikkel van die onselfgenoegsame selfstandigheid van elke menslike aktiwiteit. ${ }^{13}$ Hiersonder loop hy gevaar om in nostalgie en/of reaksionisme te verval deur 'n oormatige verlange na 'n vervloë tydperk of deur verbete pogings tot die herinstelling van minder gedifferensieerde lewensomstandighede. Andersyds kan 'n wanopvatting van die integrasiebeginsel en 'n losmaking van die differensiasiebeginsel lei tot pogings om een lewensgebied op 'n sogenaamd moderne wyse te oorbeklemtoon en selfs tot integrator van die mens se lewe te verhef, soos byvoorbeeld gebeur in die estetisisme, die rasionalisme of die volksentrisme. In die geval van volksentrisme, byvoorbeeld, word die kulturele identiteit van die mens, die feit dat hy tot ' $n$ bepaalde volk behoort - wat immers een van 'n verskeidenheid funksionele identiteite behoort te wees - tot sentrale identiteit verhef. Dit is dan wanneer sosiale omgang en ekonomiese verkeer, kunsbevordering en etiese optrede, 'n regverdige regspraak, geloofsgemeenskap en dergelike meer gereserveer word vir volksgenote, en alle ander mense uitgesluit word uit die binnekring van 'ons mense' wat selfs oor lyke heen voorkeurbehandeling moet geniet.

Aangesien die historiese beginsel van differensiasie 'n erkenning van die vryheid in eie bevoegdheid van elke lewensfeer veronderstel, kan 'n harmoniese persoonlikheidsontsluiting egter slegs voorkom indien die integrasie vanuit die sentrale identiteit plaasvind, en nie indien een van die funksionele identiteite van die mens tot integrator verhef word nie. Hierdie stand van sake is ook in ooreenstemming met die funderende posisie van die ekonomiese aspek ten opsigte van die estetiese aspek in Dooyeweerd se kosmologie. Vir die historiese ontsluitingsproses impliseer dit dat 'n harmoniese kultuurontwikkeling en identiteitsvorming slegs daar kan plaasvind waar sprake is van 'kultuurekonomie' en 'identiteitsekonomie'. Onder kultuurekonomie word dan verstaan die vermyding van oormatige ontwikkeling van een lewensvorm (soos die vrye mark in 'n kapitalistiese sisteem of die staat - wat as onderneming georganiseer is - in 'n kommunistiese sisteem ${ }^{14}$ ) ten koste van ander menslike samelewingsvorme. Onder

13 Vergelyk in hicrdic verband Rookmaaker (1978b) se klem op dic feit dat 'n gedifferensiecrde kuns geen eksterne 'regverdiging' nodig het nie, maar tog nic los staan van die samelewing nie, omdat dit deel is van dic mens se kultuurtaak, en omdat dit in sy selfstandige bestaan op sy eic, tipies-estetiese wyse getuienis lewer van dic kunstenaar se religieuse gerigtheid. Hierdie visie staan egter tecnoor 'n funksionalistiese sinbeskouing wa geen oog meer het vir die cenheid van 'n sinvolle werklikheid nie, en wat elke ding slegs vanuit homself wil verstaan (Valenkamp, 1989:12).

14 Kyk Van Nickerk (1985:44) in verband met die gemeenskaplike humanistiese religieuse wortels waaruit sowel kapitalisme as sosialisme ontspruit, en die pogings tot oormatige ontwikkeling van onderskcidelik dic mark en die onderneming in hierdic sisteme, wat albei teenoor 'n reformatoriese ekonomiese belcid van rentmeestcrskap en naastcliefde staan. 
identiteitsekonomie word op soortgelyke wyse verstaan die vermyding van die oormatige ontwikkeling van een funksionele identiteit (soos die beroepsidentiteit van die werkslaaf of die estetiese subjektiwiteit van die boheem-kunstenaar) ten koste van ander gedifferensieerde funksies van die menslike bestaan. Hierdeur kom ook 'n insig in en erkenning van die vryheid in eie bevoegdheid van elke anders geaarde lewensvorm in 'n gedifferensieerde samelewing na vore, sowel as 'n besef van die belang van menslike vorming tot relatiewe veelsydigheid.

Maar ook die historiese kontinuïteitsbeginsel (Dooyeweerd, 1955:243) is van deurslaggewende belang by die vorming van die mens se funksionele identiteit. Wanneer die mens se bande met die verlede op 'n rewolusionêre wyse verbreek word, wanneer hy sy identiteit moet vorm in teenstelling tot sy eie persoonlike geskiedenis, wanneer hy op 'n gevorderde stadium van sy lewe die keuse maak om 'weer voor te begin', miskien omdat hy deur omstandighede van buite gedwing is of voel, wanneer hy nie in staat is om sy verlede positief te verwerk nie, ry dit 'n harmoniese en kontinue identiteitsontwikkeling in die wiele, wat daartoe mag lei dat hy onseker raak oor homself, sy lewensrigting, ideale en vermoëns. Slegs waar daar sprake is van 'n ingrypende verandering wat plaasgevind het op grond van 'n buitengewone sterk innerlike oortuiging, word dergelike gevolge van diskontinuïteit getemper. Dit gebeur in gevalle waar funksionele identiteitsveranderinge genoodsaak word deur dit wat die mens van homself qua sentrale identiteit verg, ten einde op hierdie vlak 'n ervaring van wat in die Psigologie as 'kognitiewe dissonansie'15 bekend staan, te vermy.

\subsection{Die sinvraag in die wetenskap}

' $n$ Grondliggende insig in die Bybelse antwoord op die sinvraag behoort implikasies vir die funksionele identiteit van die wetenskaplike te hê. In alle teoretisering kom tewens 'n beter of 'n gebrekkiger insig in die sinprobleem implisiet of eksplisiet op tipies wetenskaplike wyse na vore. 'n Erkenning van die sin-karakter van die werklikheid beteken 'n erkenning van God as Skepper wat met sy skeppingswoord of wet-woord die gestruktureerde funksionering van elke ding na sy aard waarborg. 'n Dergelike Bybelse oorsprongsidee impliseer ook 'n erkenning van die sin-samehang (Dooye-

15 Kognitiewe dissonansic kan in hierdie geval voorkom waar die mens daarvan bewus raak dat sy persoonlike geskiedenis, keuses en handelinge in konflik verkeer met sy religieuse selfkennis of -konsep, soos dit gebeur in die lewe van die Christen met sy skuldbesef en daaglikse bekering. Uiteraard omvat dit meer as die mens se kognitiewe funksic en reik dit ook dieper, sodat miskien eerder gepraat kan word van 'n eksistensiële dissonansie. 
weerd, 1955:3-4), en daarmee die heenwysing van elke sin-sy of aspek van die werklikheid na ander aspekte, waardeur elke aspek op sy eie wyse, dit wil sê onderworpe aan die struktuurbeginsel van daardie besondere aspek, as't ware 'n spieëlbeeld bevat van alle ander aspekte (Dooyeweerd, 1955:7). Hierdie insig is van besondere belang vir die vakfilosofieë en die vakwetenskappe, aangesien dit die basis vorm van elementêre grondbegrippe waarsonder geen wetenskaplike kan klaarkom nie. Voorts is 'n visie op die sin van die werklikheid as totaliteit, en daarmee ook die antwoord op die vraag na die sin van wetenskapsbeoefening, vir die Christen geleë in Gods Koninkryk met Christus as hoof en onderworpe aan die sentrale liefdeswet. Wetenskap behoort dus vir die Christen Koninkrykswerk te wees, uit liefde vir God en die naaste en met respek vir'n geordende, veelkantige werklikheid.

Die Christenwetenskaplike wie se voorwetenskaplike geloofsantwoord op die sinvraag op gespanne voet verkeer met sy wetenskaplike antwoord daarop, word deur die Woord opgeroep tot geïntegreerdheid van lewe. Die Skrif laat immers geen tweedeling van die lewe in 'n godsdienstige en 'n 'neutrale' sfeer toe nie. Wetenskap behoort vir die Christen 'n saak te wees waarby hy eksistensieel betrokke is omdat grondvrae ook daarin, soos in alle ander lewensgebiede, beantwoord moet word. Daar moet gewaak word teen die versoeking om die maklike, dualistiese uitweg te kies deur probleme van sin en identiteit te beperk tot nie-wetenskaplike (veral geloofs- en etiese) probleme, wat dan eksklusief as eksistensiële probleme bestempel word, teenoor wetenskaplike probleme wat sogenaamd objektief aan die orde kom. ${ }^{16}$ Wanneer daar dan tog gepoog word om Christenskap in verband te bring met wetenskapsbeoefening, lei 'n dergelike dualisme bykans onvermydelik tot die siening dat die wetenskap 'n instrument sou wees, soos byvoorbeeld 'n knipmes, wat eties goed of sleg ingespan sou kon word.

\section{TEN SLOTTE}

Menslike identiteit blyk 'n komplekse saak te wees: dit hang ten nouste saam met die antwoord op die religieuse vraag na sin en omvat nie slegs die mens se hartsgesteldheid

16 Vergelyk in hierdic verband 'n formulering van Rossouw (1981:1) wat, waarskynlik onbedocld, $\log$ gevaar loop om die indruk van 'n dergelike dualisme te skep: "Dic vraag na dic sin van dic lewe kan nic in kliniese afgetrokkenheid gestel word nic. Dit is nie ' wetenskaplike vraag nic. Die ingesteldheid wat daarby pas, is dié van innerlike bewoënheid. Die verwagting waaraan dit uitdrukking gee, is nie die verwagting van 'n teoretiese hipotese waarvan die bekragtiging of wecrlegging ons bestaan as mense ongemoeid laat nie. Dit is vecleer 'n verwagting wat die karakter het van 'n hunkering ...." 
as sentrale lewensbepalende identiteit waardeur hy gestempel word tot lid van 'n bepaalde religieuse gemeenskap nie, maar ook die verskeidenheid verhoudinge en aktiwiteite waaraan hy deel het en waarvan die wyse tot deelname juis ten diepste deur sy sentrale identiteit bepaal behoort te word. Daarby het albei dimensies van identiteit vele fasette, onder andere ' $n$ psigiese faset wat nader omskryf kan word as die selfgevoel van die mens. 'n Negatiewe selfgevoel dui op die psigiese uitwerking van 'n identiteitsbelewing wat mank gaan aan 'n positiewe ervaring van sin en eie-waarde, terwyl 'n positiewe selfgevoel aan die ander kant weer' $n$ aanduiding is van sekerheidsgevoelens aangaande die positiewe waarde van die lewensrigting, -ideale en vermoëns van die mens. Die menslike identiteitsbesef of selfbeeld bevat ook nog vele ander komponente, soos 'n fisiese komponent (selfbeheersing) 'n kognitiewe komponent (selfkennis), 'n etiese komponent (selfliefde), 'n pistiese komponent (selfvertroue of geloof in jouself) en dergelike meer. ${ }^{17}$

Juis omdat ware selfkennis, wat afhanklik is van ware Godskennis (Dooyeweerd, 1955:562; 1972:184) ook altyd 'n besef van die menslike feilbaarheid sal bevat, kan geen werklikheidsgetroue selfbeeld totaal positief wees nie - trouens, dit sou nie slegs dui op 'n gebrek aan insig in die realiteit van die sondeval nie, maar dit sou ook 'n werklikheidsvreemde selfoorskatting en selftevredenheid meebring.

Terwyl die mens se sentrale identiteit (wat differensieer tot 'n verskeidenheid funksionele identiteite) dan ten diepste bepaal word deur sy implisiete of eksplisiete voorteoretiese antwoord op die sinvraag, is sy reaksie op die geloofsappèl van die Woord van kardinale belang. Waar daar geen Skriftuurlike antwoord op hierdie vraag gegee word nie, beteken dit egter nie dat die bestaan en belang van die sinvraag vir 'n bepaalde persoon opgehef word nie, maar wel dat daar ' $n$ ideologies verdraaide antwoord hierop gegee word en dat ook hierdie ideologiese gerigtheid prakties na vore kom in die mens se kultuuraktiwiteite. Ideologieë verskaf ook 'sin' aan 'n mens se lewe, maar dan 'n valse sin.

Ten opsigte van die struktuur van die menslike selfheid geld die geskapenheid na Gods beeld as sentrale kenmerk (Dooyeweerd, 1972:185), sodat die semen religionis ${ }^{18}$ by alle mense aanwesig is - 'n gegewe wat beteken dat die mens se hart altyd 'n sekere eksistensiële gerigtheid of radikale vertrouensbetrokkenheid openbaar. ${ }^{19}$ En omdat

17 Tans kan nie nader op al hicrdic fasette van identiteit ingegaan word nic - dit is dic taak van 'n spesialis op dic gebicd van die Psigologic.

18 Dit is die ingebore godsbesef volgens Calvyn - vergelyk Smit (1991:88)

19 In Bybelse geloofstaal gesproke, beteken hicrdic geskapenheid na Gods beeld dat dit God se bedocling was dat die mens hier op aarde sy 'verteenwoordiger' moet wees, sy Naam dus in alles moet verheerlik. 
Christus die strukturele voorwaardes vir die menslike bestaan in stand hou, is selfs die mees verbete poging om in niks te glo nie, tot mislukking gedoem, soos wat Olthuis (1978:167) ook tereg beklemtoon:

Man cannot but believe - even if it is in futility. Man cannot but commit himself - even if it is to meaninglessness. For it is the "god" confessed that gives unity and purpose to life. When there is a plethora of such gods, there is no real unity of self nor of community. To be a self is to have a god; to have one god is to have a life of one piece.

Wat betref die spesifieke rigting waarna die selfheid heenwys, is daar egter ten diepste slegs twee moontlikhede wat mekaar volgens die Bybelse beginsel van die antitese wedersyds uitsluit: 'n gerigtheid of op God deur Christus, of 'n afvallige gerigtheid op verabsoluteerde skeppingsgegewens. Ware kennis van God, tesame met ware selfkennis as besef van die mens se sentrale identiteit in Christus, setel albei in die hart as religieuse sentrum van die bestaan. Hierdie religieuse selfkennis is slegs moontlik deur die Bybelse Woordopenbaring en die wederbarende werking van die Gees van God, waarin die mens homself leer ken as oorspronklik betrokke op God, as radikaal en totaal van God vervreem in sy afvallige staat, maar ook as begenadigde in Christus. Die mens wat 'n besef hiervan het, se oë word geopen, nie net vir die sin van sy eie subjektiewe bestaan nie, maar ook vir die objektiewe sin van die werklikheid as God se skepping wat in die gestruktureerdheid en in die instandhouding daarvan heenwys na Hom.

\section{BRONNELYS}

ALLPORT, G.W. 1\%1. Pattern and Growth in Personality. New York : Holt, Rinehart and Winston.

BOTHA, M.E. 1978. Is kultuurbeocfening nog sinvol? Potchefstroom : PU vir CHO. (Wctenskaplike bydracs van dic PU vir (CHO. Recks F1. Nr. 126.)

BOTHA, M.E. 1990. Metateoreticsc perspektiewe op dic sosiale wetenskappc. Potchefstroom : PU vir C.HO. (Wetenskaplike bydracs van dic PU vir CHO. Recks A. Nr. 73.)

CRONJe, C.P. 1990. Dic samchang denke-gevocl: 'n antropologiesc basis vir dic didaktick. Tydskrif vir Christelike Wetenskap, 26(3\&4):30-48.

DOOYEWEERD, H. 1953 (1); 1955 (2). A New Critique of Theoretical Thought. (Translated by D. Freeman and B. Young.) Philadelphia : The Presbytcrian and Reformed Publishing Co.

DOOYEWEERD, H. 1972. In the Twilight of Western Thought. Philadelphia : The Presbyterian and Reformed Publishing Co.

FOWLER, S. 1983. Karl Marx - Secular Messiah. Potchefstroom : PU vir CHO. (Instituut vir Reformatoricse Studic. Studiestuk nr. 184.)

FOWLER, S. 1985. Biblical Studies in the Gospel and Socicty. Potchefstroom : Instituut vir Reformatoricsc Studics. 
FRANKL, V.E. 1963. Man's Search for Meaning: An Introduction to Logotherapy. New York : Washington Square Press.

FRANKL, V.E. 1970. Psychotherapy and Existentialism: Selected Papers on Logotherapy. London : Souvenir Press.

FRANKL, V.E. 1985. Die Sinnfrage in der Psychotherapie. München : Piper.

KALSBEEK, L. 1970. De Wijsbegeerte der Wetsidee: proeve van een christelijke filosofie. Amsterdam Buijten \& Schipperheijn. (Christelijk Perspektief. Deel XVI.)

MADDI, S.R. 1976. Personality Theories: A Comparative Analysis. 3rd ed. Homewood, Illinois : The Dorsey Press.

OLTHUIS, J.H. 1978. Visions of Life and Ways of Life: The Nature of Religion. (In De Graaff, A.H. \& Olthuis, J.H., eds. Toward a Biblical View of Man; Some Readings. Toronto : AACS. p. 164 190.)

OLTHUIS, J.H. 1985. An Integral Anthropological Model. Potchefstroom : PU vir CHO (Wetcnskaplike bydraes van die PU vir CHO. Reeks J3. Nr. 9.)

OUWENEEL, W.J. 1984a. Hart en ziel: een christelijke kijk op de psychologic. Amsterdam : Buijten \& Schipperheijn.

OUWENEEL, WJ. 1984b. Psychologic: een christelijke kijk op het mentale leven. Amsterdam : Buijten \& Schipperheijn.

OUWENEEL, WJ. 1987. De macht van het sciëntisme. Potchefstroom : PU vir CHO. (Wetenskaplike bydracs van dic PU vir CHO. Reeks J2. Nr. 13.)

ROOKMAAKER, H.R. 1978a. Modern Art and the Death of a Culturc. 2nd ed. Leicester : Inter-Varsity Press.

ROOKMAAKER, H.R. 1978b. Art Needs No Justification. Leicester : Inter-Varsity Press.

ROSSOUW, H.W. 1981. Die sin van die lewe. Kaapstad: Tafelberg.

SMIT, J.H. 1988. Betckenis van 'n Christelike mensbeskouing vir die geesteswetenskappe. Potchefstroom : PU vir CHO. (Wetenskaplike bydraes van die PU vir CHO. Recks J3. Nr. 20.)

SMIT, J.H. 1991. Die antropologie van Johannes Calvyn (1509-1564). Tydskrif vir Christelike Wetenskap, 27(4):81-120.

STRAUSS, D.F.M. 1979. Die uniekheid van die mens. Bloemfontein : UOVS. (Intreerede.)

STRAUSS, D.F.M. 1989. Die mens en sy wêreld. Bloemfontein : Tckskor.

TROOST, A. 1958. Casuïstick en situatie-ethiek: een methodologische terreinverkenning. Utrecht Libertas.

VALENKAMP, M. 1989. Die sin van ons bestaan. Potchefstroom : Instituut vir Reformatoriese Studies. (Wetenskaplike Bydracs van die PU vir CHO. Reeks F1. Nr. 264.)

VAN NIEKERK, A.A. 1986. Humor en lcwensin. Tydskrif vir Geesteswetenskappe, 26(3):184-193, Sept.

VAN NIEKERK, M, 1991a. Determinisme en getemperde detcrminisme in enkele psigologiese beskouings oor sin en identiteit. Koers, 56(2):123-138.

VAN NIEKERK, M. 1991b. Dic ontwikkeling van 'n cic vakfilosofiese metode van kunswerkondersock in aansluiting by verteenwoordigers van die reformatoriese tradisic. (Navorsingsverslag vir Wetenskapsleer, PU vir CHO, ongepublisecr.)

VAN NIEKERK, M. 1992. Vryheid in menslike identiteitsvorming en sinbelewing: alternaticwe vir deterministiese benaderings. Koers, 57(1):59-74.

VAN NIEKERK, P.J. 1985. Capitalism or Socialism: A Spurious Dilemma. Koers, 50(1):35-50

WOLTERSTORFF, N. 1980. Art in Action: Toward a Christian Aesthetic. Grand Rapids, Mich. : Eerdmans. 